\title{
Rosuvastatin Reduces Neointima Formation in a Rat Model of BALLOON INJURY
}

\author{
M. R. Preusch ${ }^{1,2}$, A. Vanakaris ${ }^{1}$, F. Bea ${ }^{1}$, N. Ieronimakis ${ }^{2}$, T. Shimizu ${ }^{2}$, M. Konstandin ${ }^{1}$, S. Morris- \\ Rosenfeld $^{1}$, C. Albrecht ${ }^{1}$, A. Kranzhöfer ${ }^{3}$, H. A. Katus ${ }^{1}$, E. Blessing ${ }^{1 *}$, R. Kranzhöfer ${ }^{1 *}$ \\ ${ }^{1}$ Department of Internal Medicine III, University of Heidelberg, Heidelberg, Germany ${ }^{2}$ Department of Pathology, University of \\ Washington, Seattle, USA, \\ ${ }^{3}$ Department of Nephrology, Hannover Medical School, Hannover, Germany
}

\begin{abstract}
Background: Processes of restenosis, following arterial injury, are complex involving different cell types producing various cytokines and enzymes. Among those enzymes, smooth muscle cell-derived matrix metalloproteinases (MMPs) are thought to take part in cell migration, degrading of extracellular matrix, and neointima formation. MMP-9, also known as gelatinase $B$, is expressed immediately after vascular injury and its expression and activity can be inhibited by statins. Using an established in vivo model of vascular injury, we investigated the effect of the HMG-CoA reductase inhibitor rosuvastatin on MMP-9 expression and neointima formation.

Materials and Methods: 14-week old male Sprague Dawley rats underwent balloon injury of the common carotid artery. Half of the animals received rosuvastatin (20 mg/kg body weight/day) via oral gavage, beginning 3 days prior to injury. Gelatinase activity and neointima formation were analyzed 3 days and 14 days after balloon injury, respectively. 14 days after vascular injury, proliferative activity was assessed by staining for $\mathrm{Ki} 67$.

Results: After 14 days, animals in the rosuvastatin group showed a decrease in total neointima formation $\left(0.194 \pm 0.01 \mathrm{~mm}^{2}\right.$ versus $\left.0.124 \pm 0.02 \mathrm{~mm}^{2}, \mathrm{p}<0.05\right)$ as well as a reduced intima/media ratio $(1.26 \pm 0.1$ versus $0.75 \pm 0.09, \mathrm{p}<0.05)$. Balloon injury resulted in increased activity of MMP-9 3 days after intervention for both rosuvastatin treated animals and controls with no significant difference observed between the groups. There was a trend towards a reduction in the number of Ki67-positive cells 14 days after injury.

Conclusions: Rosuvastatin attenuates neointima formation without affecting early MMP-9 activity in a rat model of vascular injury.
\end{abstract}

\section{INTRODUCTION}

Arterial restenosis following balloon angioplasty remains a common clinical limitation even after stent

\footnotetext{
* Both authors contributed equally to this study.
}

implantation [1]. This effect is mainly caused by accelerated neointima formation due to smooth muscle cell migration and proliferation after endothelial damage [2]. Several pathophysiological mechanisms have been discussed. Some studies suggest profuse vascular wound healing due to adjacent endothelial cells and endothelial progenitors [3, 4]. Others have demonstrated a TGF- $\beta$-dependent mechanism of constrictive arterial remodeling and formation of intimal thickening composed of smooth muscle cells [5]. In part, vascular remodeling is also induced by the release of SMC matrix degrading enzymes, such as matrix metalloproteinases and the tissue inhibitors of matrix metalloproteinases (TIMP) [6, 7]. In particular, MMP9 is upregulated following vessel injury [8]. Inhibition of MMPs resulted in reduced SMC proliferation and inhibition of neointimal hyperplasia $[9,10]$. Since it is known that hydroxymethylglutaryl coenzyme A (HMG-CoA) reductase inhibitors are beneficial in primary and secondary prevention of cardiovascular disease, and that their pleiotropic effects are independent of their lipid-lowering potential, some studies have focused on the effect of statin therapy on prevention of restenosis [11-17]. Several in vitro and in vivo studies demonstrated reduction of MMP-9 expression following statin treatment $[19,20]$.

Recently, it has been demonstrated that the potent HMG-CoA reductase inhibitor rosuvastatin reduces neointima formation in a hypertensive rat model [16]. Furthermore rosuvastatin promotes bone-marrow dependent re-endothelialization and reduces neointima formation in mice [21].

Our study evaluated the effect of rosuvastatin on MMP-9 expression and neointima formation in a rat model of vascular injury.

\section{Materials And Methods \\ Animals and Drug Treatment}

Twenty two male Sprague Dawley rats (380 - 420g; Charles River Laboratories, Sulzfeld, Germany) at the age of 14 weeks were kept within the animal care facility of the University of Heidelberg. Animals received free water and food (standard chow diet) ad li- 
bitum in a temperature controlled room with a 12 hour light/dark cycle. Animals were randomly divided into rosuvastatin treated group and controls. Starting three days prior to balloon injury, half the rats received rosuvastatin $(20 \mathrm{mg} / \mathrm{kg}$ bodyweight / day) via oral gavage. A number of the rats were euthanized 3 days after balloon injury for immunoblot and gelatinolytic assay. For the evaluation of neointima formation, additional rats were euthanized 14 days after injury. Housing and care of animals, and procedures carried out in this study were performed in accordance with the guidelines and regulations composed by the Animal Care Committee of the University of Heidelberg.

\section{BALLOON INJURY}

Rats were anesthetized by intraperitoneal injection of ketamine $(100 \mathrm{mg} / \mathrm{kg}$ body weight) and xylazine (15mg/kg bodyweight). After midline incision of the neck, the left external carotid artery was exposed and a $2 \mathrm{~F}$ balloon catheter (Baxter Healthcare) was introduced up to the aortic outlet of the common carotid artery. The balloon was then inflated with saline solution until a slight resistance was felt. While rotating, the balloon was pulled back through the common carotid artery to denude the endothelium. This procedure was repeated twice. Afterwards, the catheter was removed, the external carotid artery ligated and the wound was closed. Contralateral right arteries served as uninjured controls. Three and 14 days after surgery rats were anaesthetized as described previously, blood was collected from the inferior vena cava, stored for further use, and animals were euthanized by exsanguination. Rats were perfused with $20 \mathrm{ml}$ phosphatebuffered saline solution at physiological pressure via left ventricle. Left and right common carotid arteries were excised, adhering connective tissue was removed and stored at $-80^{\circ} \mathrm{C}$.

\section{Determination of Plasma Lipid Levels}

Total serum cholesterol, high-density lipoprotein (HDL) and low-density lipoprotein (LDL) cholesterol were determined enzymatically in heparinized plasma.

\section{Morphometric AnALysis of NeOINTIMA FORMATION / IMMUNOHISTOCHEMISTRY}

Common carotid arteries were serially sectioned (5 $\mu \mathrm{m})$ and stained with hematoxylin-eosin (HE). Sections were evaluated blind using computer-assisted morphometry (Olympus Mikroskopie Hamburg, Germany and Image Pro, Media Cybernetics, Silver Spring, USA). The size of the neo-intimal layer was determined as the area between internal elastic lamina and the luminal circumference (data expressed in $\mathrm{mm}^{2}$ ). Furthermore, the total number of cells was evaluated by counting nuclei. In addition, neointima/media ratios were calculated by a blinded observer.

To determine proliferation and endothelial integrity, serial sections were stained for Ki67 with a rabbit polyclonal antibody (abcam, Cambridge, UK), a rabbit von Willebrand factor antibody (Dako, Carinteria, CA, USA) and a directly FITC conjugated $\alpha$-smooth muscle actin antibody (Sigma-Aldrich, St. Luis MO, USA). Proliferation index was calculated as number of Ki67positive cells / total amount of cells.

\section{Protein EXTRACTION FOR WeStern BLOT AND GELATINOLYTIC AsSAY}

For gelatinolytic assay, frozen arteries were homogenized with lysis buffer $(50 \mathrm{mmol} / 1$ Tris-HCL, $\mathrm{pH} 7,6$; $150 \mathrm{mmol} / 1 \mathrm{NaCl} ; 5 \mathrm{mmol} / 1 \mathrm{CaCl}_{2} ; 0,05 \%$ Brij-35; 0,02\% NaN3; 1\% Triton X-100). Lysates were sheared by ultrasonic disruption, and centrifuged at 14.000 r.p.m at $4^{\circ} \mathrm{C}$ for $10 \mathrm{~min}$. Supernatants were used as whole cell lysates and protein concentration was determined using the Bradford method (Bio-Rad Protein Assay).

\section{GELATINOLYTIC ASSAY}

Ten $\mu \mathrm{g}$ protein were used to analyze vessel tissue gelatinase activity. Gelatinase activity was detected in a 10\% gelatine gel (Invitrogen, Carlsbad, USA) using SDS running buffer (all chemicals Invitrogen, Carlsbad, USA). After electrophoresis, gels were incubated with zymogram renaturing buffer for $30 \mathrm{~min}$ and developed in zymogram developing buffer for 12 hours. Gels were stained with $0.125 \%$ Coomassie blue R-250 for $30 \mathrm{~min}$ in $10 \%$ acetic acid and $50 \%$ methanol. Finally, gels were destained with a solution containing $10 \%$ acetic acid and 10\% methanol until clear bands of gelatinolysis appeared on a dark blue background. The molecular weight of the gelatinolytic bands was estimated by comparison with prestained molecular weight markers (Bio-Rad, Munich, Germany). Gels were dried and scanned by densitometry.

\section{WESTERN BLOTTING}

Ten $\mu \mathrm{g}$ of protein were seperated by $10 \%$ SDS-PAGE Gel (Invitrogen, Carlsbad, USA) and transferred to nitrocellulose membranes (Schleicher und Schuell, Germany). After blocking ( $5 \%$ nonfat milk powder dissolved in TBST) the membrane was incubated with primary antibody (polyclonal goat anti rat MMP-9, dilution $1: 2000$ ) overnight at $4{ }^{\circ} \mathrm{C}$, washed three times with TBST, followed by incubation with a secondary antibody for 1 hour at room temperature. After washing, bands were visualized with ECL (Amersham Biosience, USA), recorded on hyperfilm (Amersham) and quantified by densitometry (Bio-Rad). Antibodies, used in this study, were purchased from Santa Cruz Biotechnology, Santa Cruz, USA.

\section{STATISTICAL ANALYSIS}

All data were expressed as mean \pm SEM or as mean $\pm \mathrm{SD}$, as indicated. Significant differences between means in plasma lipid profiles were determined with the two-tailed unpaired student's $t$-test, differences in neointima size using the Mann-Whitney u-test. A p-value $<0.05$ was considered statistically significant. 


\section{RESULTS}

\section{Effect on Plasma Lipid Levels}

At the time of euthanasia, animals showed no significant differences in total cholesterol, HDL and LDL cholesterol. Furthermore, there were no differences in bodyweight (Table 1).

\section{MORPHOMETRICAL ANALYSIS}

Compared to the controls, treatment with rosuvastatin lead to a decrease of neointima area $(0.194 \pm 0.01$ $\mathrm{mm}^{2}$ versus $\left.0.124 \pm 0.02 \mathrm{~mm}^{2}, \quad \mathrm{p}<0.05\right)$ and intima/media ratio $(1.26 \pm 0.1$ versus $0.75 \pm 0.09$, $\mathrm{p}<0.05) 14$ days after injury (Fig. 1). Total number of cell nuclei within the neointima was also significantly reduced in the arteries of rosuvastatin-treated rats, as compared to control animals $(3950 \pm 263$ versus 5262 $\pm 248, \mathrm{p}<0.01)$.

\section{PROLIFERATION / INTEGRITY OF ENDOTHELIAL LAYER}

Ki67 staining was used to determine proliferation. There was a trend towards a reduction in the number of Ki67-positive cells in rosuvastatin-treated animals $(2.1 \pm 0.17$ versus $1.6 \pm 0.13 ; \mathrm{p}=0.058)$. However, the difference did not reach statistical significance (Fig. $2 \mathrm{AB}$ ).

Two weeks after injury, arteries still showed incomplete re-endothelialisation, as evaluated by staining with an immunofluorescence-antibody against von Willebrand factor and $\alpha$-smooth muscle actin. No significant differences between treatment groups could be detected (data not shown, Fig. 2 C).

\section{GELATINOLYTIC ACTIVITY}

Balloon injury of rat arteries upregulated expression of a $92-\mathrm{kD}$ band in the gelatin zymography 3 days after injury. No signal could be detected in the non-denudated contralateral vessels (right CCA), which suggests that these $92-\mathrm{kD}$ proteins are induced by injury. This band corresponds to a form of rat $95-\mathrm{kD}$ type IV collagenase/gelatinase (MMP-9) [21]. However no difference could be detected between rosuvastatin treated and control rats $(3754 \pm 1074$ versus $3488 \pm$ 1816; Fig. 3A).

\section{WESTERN BLOTTING}

MMP-9 protein expression in CCA was determined by Western blot in rosuvastatin treated rats and controls. Balloon injury resulted in an induction of MMP-9 ex- pression in arteries 3 days after de-endothelialization. Contralateral vessels in the same rats showed no induction of MMP-9. Again, there was no significant difference between rosuvastatin treated and control animals (Fig. 3B).

\section{Discussion}

Percutaneous coronary interventions (PCI) are widely used for treatment of coronary heart disease. However, long-term benefit is often limited by restenosis, occurring in about $30 \%$ of patients following bare metal stent implantation [23]. Introduction of drug eluting stents has decreased the incidence of restenosis significantly but is associated with several problems such as stent thrombosis [24].

Remodeling processes of the extracellular matrix by MMPs are essential for neointima formation in postangioplasty restenosis as well as in aortocoronary vein graft vasculopathy $[8,25]$. HMG-CoA reductase inhibitors are known to suppress MMP-expression and are therefore a potential treatment option in restenosis prevention $[19,20,26]$.

Using a standard animal model of vascular injury we were able to demonstrate a significant reduction of neointima formation in rats treated with rosuvastatin. These data are in accordance with other studies in rats and mice, whereas Kappert et al. (2006) only observed an increase in luminal circumference but no difference in total neointima size, nor in intima/media ratio [16, 17, 26]. Prevention of restenosis by HMG-CoA reductase inhibitors might be dose-dependent. Kappert et al. (2006) used rosuvastatin in a dose of only $1 \mathrm{mg} / \mathrm{kg} / \mathrm{d}$ whereas we and van de Harst (2006) administered rosuvastatin in a dose of $20 \mathrm{mg} / \mathrm{kg} / \mathrm{d}$, a dose previously demonstrated to inhibit hepatic HMG-CoA reductase by $90 \%$ in rats $[16,17,18]$.

It has been demonstrated that vascular injury causes early upregulation of matrix metalloproteinase-2 (MMP-2, gelatinase A) and matrixmetalloproteinase-9 (MMP-9, gelatinase B) and therefore might play an important role in SMC migration [8]. Using balloon deendothelialization, an effective method for causing severe vascular damage, we showed that gelatinase B activity was upregulated 3 days after intervention. However, rosuvastatin treatment had no effect on expression or gelatinolytic activity of gelatinase B after balloon injury. Therefore, prevention of restenosis by rosuvastatin must act via an MMP-independent mechanism.

Consistent with other studies, we found Ki67-positive cells within the neointima of all animals 14 days after injury. There was a trend towards reduced

Table 1. Body weight and lipid profile. No significant difference in levels of total cholesterol, HDL and LDL as well as body weight could be detected.

\begin{tabular}{lllllll}
\hline & $\mathrm{n}$ & $\begin{array}{l}\text { Body Weight } \\
(\mathrm{gram})\end{array}$ & $\begin{array}{l}\text { Total Cholesterol } \\
(\mathrm{mg} / \mathrm{dl})\end{array}$ & $\begin{array}{l}\text { LDL Cholesterol } \\
(\mathrm{mg} / \mathrm{dl})\end{array}$ & $\begin{array}{l}\text { HDL Cholesterol } \\
(\mathrm{mg} / \mathrm{dl})\end{array}$ & $\begin{array}{l}\text { Triglycerides } \\
(\mathrm{mg} / \mathrm{dl})\end{array}$ \\
\hline Rosuvastatin & 10 & $416 \pm 23$ & $49 \pm 14$ & $23 \pm 9$ & $15 \pm 5$ & $52 \pm 25$ \\
Control & 10 & $409 \pm 18$ & $49 \pm 4$ & $23 \pm 3$ & $14 \pm 3$ & $71 \pm 23$ \\
\hline
\end{tabular}

Mean \pm SD 

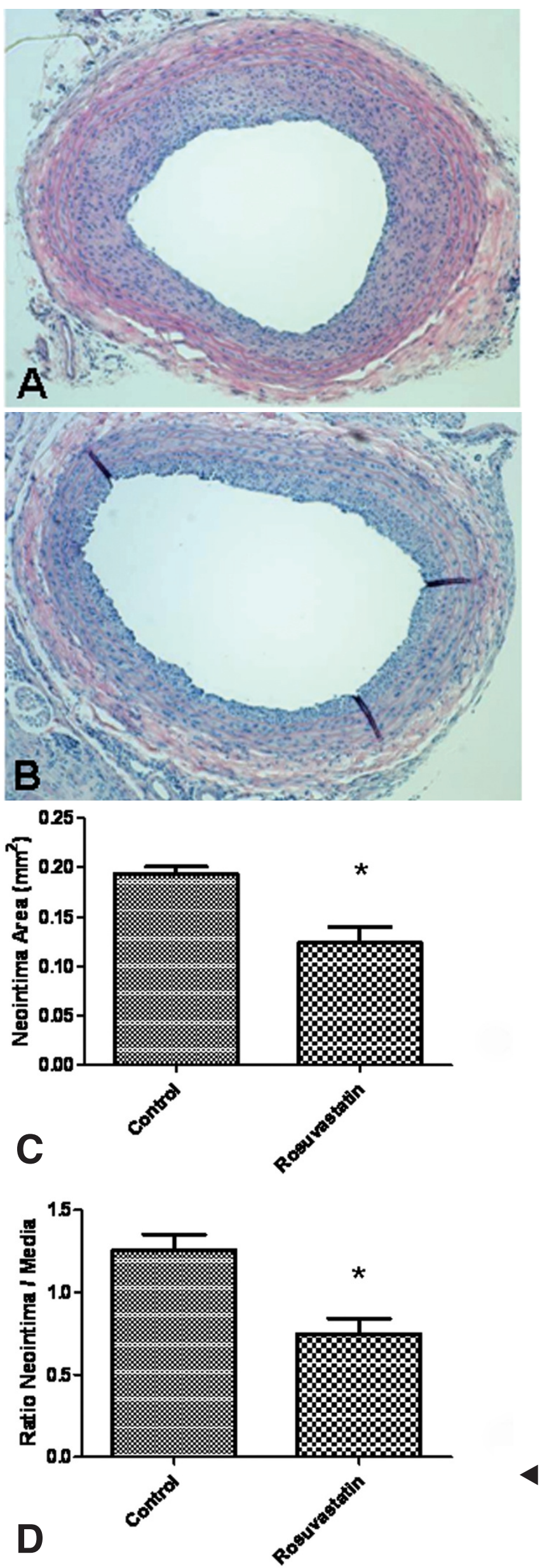
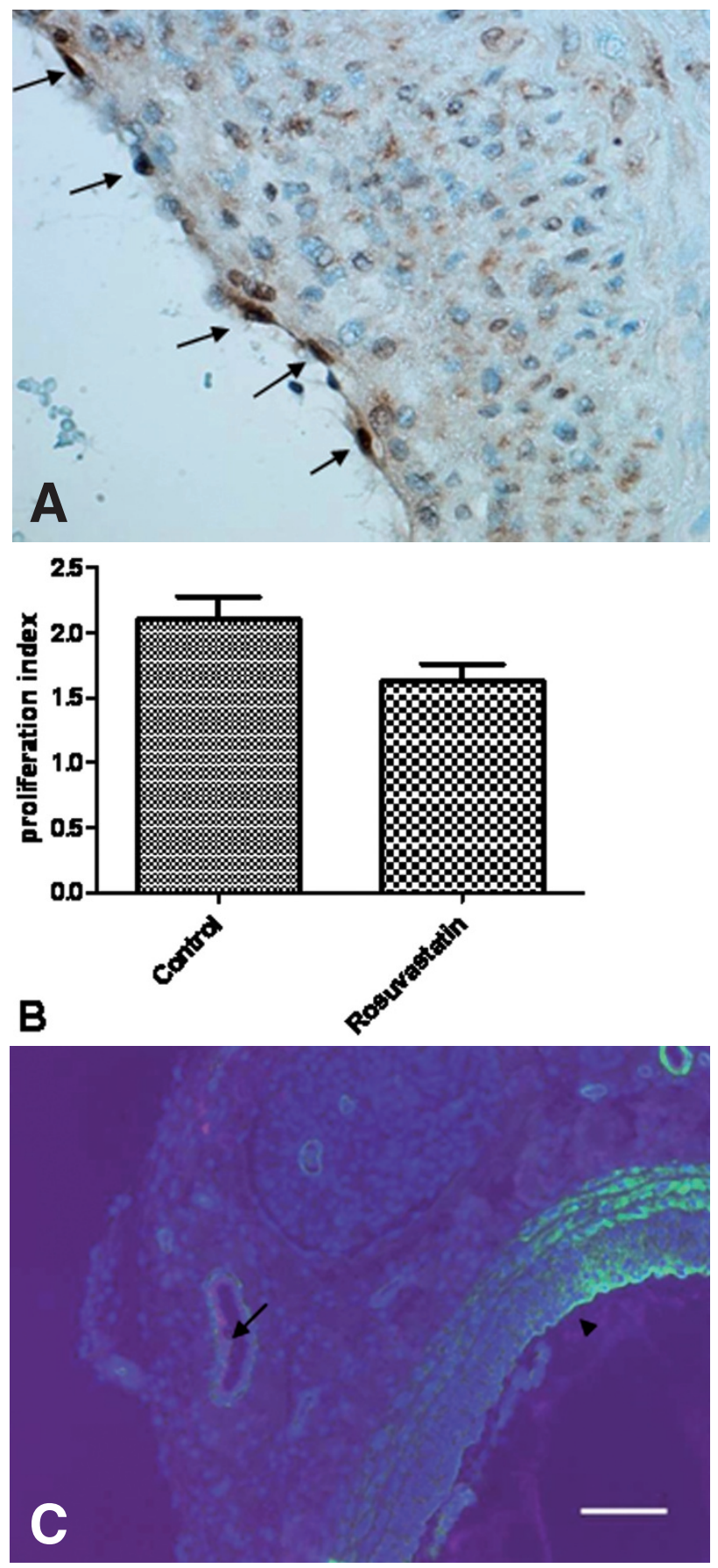

Fig. 2. Ki67-positive cells (arrows) within the neointima at 14 days after injury of a control animal. (A) Rosuvastatin treatment tended to reduce the proliferation index within the neointima (number of Ki67-positive cells / total amount of cells). However at day 14 no significant difference could be detected $(\mathrm{p}=0.058)$. (B) Staining with immunofluorescence-labeled antibody against von Willebrand factor (secondary antibody alexa 594 in red) and _-smooth muscle actin in FITC (green) demonstrated that reendotheliazation was not completed 14 days after injury (arrow head) (_-smooth muscle actin in FITC, green). An adventitial artery is shown as a positive control (arrow). (C) Scale Bar $=100 \mu \mathrm{m}$.

Fig. 1. Neonintima formation of the common carotid artery (hematoxylin / eosin staining) 14 days after balloon injury in a control animal (A) and an animal treated with rosuvastatin. (B) Treatment with rosuvastatin leads to a reduction of neointima size, as well as a reduction of neointima / media ratio. (C, D). 


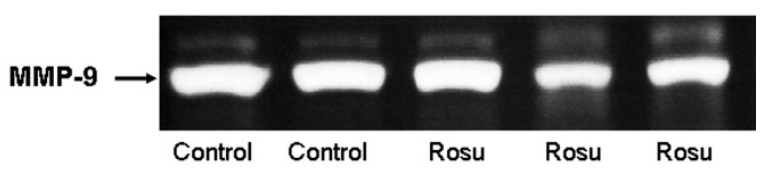

B

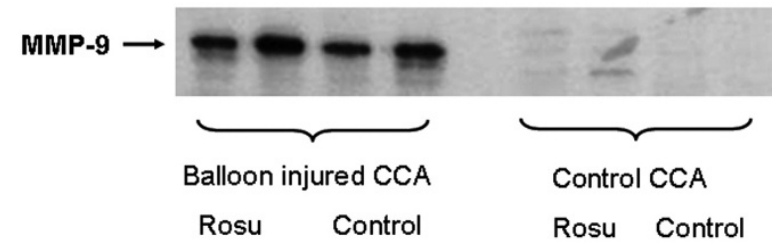

Fig 3. Gelatinolytic activity assay demonstrated an induction of $92-\mathrm{kD}$ gelatinase $\mathrm{B}$ three days after balloon injury in rat common carotid artery. No difference between rosuvastatin treated and controls could be detected (A). Western blot confirmed MMP-9 expression in rat common carotid arteries three days after balloon injury. No significant expression could be detected in non-injured contralateral arteries, which served as controls (B).

expression in the rosuvastatin-treated group, compared to controls. Proliferation after arterial injury is commonly described as an early event which reaches a maximum within the intimal layer between day four and seven [27]. It is possible that the observed trend in our study would reach statistical significance at an earlier time point, as evaluated in the present study. Other studies also demonstrated a strong association between severe arterial injury with disruption of the internal elastic lamina (IEL) and expression of Ki67. Thus, variability in severity of injury between different studies may also contribute to differences in time course of proliferation [28]. Consistent with other studies, proliferating cells are nearly exclusively located in the luminal surface. Recently published data demonstrated antiproliferative effects of Rosuvastatin in an ex-vivo model of balloon injury via urokinasetype plasminogen activator receptor (uPAR) [29]. Furthermore, data acquired by our group and others showed inhibitory effects of statins on the activity of the transcription factors Egr-1, NF-kappaB, and AP-1 $[30,31]$.

The adjacent cells of the intact vascular wall are mainly responsible for wound repair after injury [3]. Recent data support the possibility that bone marrowderived cells, circulating in the blood stream contribute to neoangiogenesis and accelerated re-endothelialisation leading to a reduction of neointima formation [32, 33]. Werner et al. (2002) demonstrated the beneficial effects of endothelial progenitor cells in a mouse model of carotid injury: rosuvastatin treatment accelerated re-endothelialisation and significantly reduced neointimal formation [21]. However, it remains unclear whether this is due to a direct effect of statin therapy or due to a statin-mediated increase in the number of circulating, immature, endothelial cells [34]. We observed a lack of re-endothelialisation at 14 days after injury that was not affected by statin treatment. Differences in endothelial recovery between studies can be explained by variable distances between untraumatized endothelium and denuded areas, since regeneration, at least in part, starts from the adjacent non-injured endothelial layer [35]. It has been reported that even as late as six weeks after injury, some areas of the artery still remained without endothelium [36].

New data furthermore have demonstrated an association between statin treatment and the reduced risk of venous thrombosis which implies an effect of HMG-CoA reductase inhibition and the coagulation system [31, 32]. Studies demonstrated a statin-induced inhibition of the procoagulatory tissue factor and even proposed tissue factor activity as a risk predictor of restenosis after PCI and stent implantation [37, 38, 39, 40].

Clinical studies have suggested that lipid-lowering by statins protects from restenosis after coronary stenting $[41,42]$. It has been shown that rosuvastatin significantly decreased LDL, cholesterol, and triglyceride levels and that high-dose rosuvastatin treatment was more effective than similar doses of atorvastatin in lowering direct LDL cholesterol [43]. In contrast, our model, at the time of necropsy, showed no differences in total cholesterol, LDL, or HDL between the groups which also confirms a cholesterol-independent effect on neointima formation in our in vivo-model. The lack of a cholesterol-lowering effect of statin treatment in rodents has been investigated in several studies and seems to be very common, even at higher doses $[44,45]$. The mechanisms how statin treatment of apoE-/- mice even causes an increase in serum cholesterol, as observed in some studies, is still unclear [46]. One possible explanation is that continuous administration of statins via chow even stimulates expression and/or activity of HMG-Co A reductase in the liver of treated mice.

In conclusion, our study demonstrates that rosuvastatin inhibits neointima formation after balloon injury and it supports the hypothesis that this effect is MMP9 independent.

Acknowledgements: We would like to thank Joachim Schmidt, Annette Buttler and Heike Ziebart for excellent technical assistance. This study was supported by a grant of AstraZeneca.

\section{REFERENCES}

1. Ferns GA, Avades TY. The mechanisms of coronary restenosis: insights from experimental models. Int J Exp Pathol. 2000;81:63-88

2. Andres V. Control of vascular smooth muscle cell growth and its implication in atherosclerosis and restenosis. Int $\mathrm{J}$ Mol Med. 1998;2:81-89

3. Carmeliet P, Moons L, Stassen JM, De Mol M, Bouché A, van den Oord JJ, Kockx M, Collen D. Vascular wound healing and neointima formation induced by perivascular electric injury in mice. Am J Pathol 1997;150:761-776

4. Takamiya M, Okigaki M, Jin D, Takai S, Nozawa Y, Adachi Y, Urao N, Tateishi K, Nomura T, Zen K, Ashihara E, Miyazaki M, Tatsumi T, Takahashi T, Matsubara H. Granulocyte colony-stimulating factor-mobi- 
lized circulating c-Kit+/Flk-1+ progenitor cells regenerate endothelium and inhibit neointimal hyperplasia after vascular injury. Arterioscler Thromb Vasc Biol 2006;26: 751-7

5. Smith JD, Bryant SR, Couper LL, Vary CP, Gotwals PJ, Koteliansky VE, Lindner V. Soluble transforming growth factor-beta type II receptor inhibits negative remodeling, fibroblast transdifferentiation, and intimal lesion formation but not endothelial growth. Circ Res. 1999;84:12121222

6. Libby P. Molecular bases of the acute coronary syndromes. Circulation 1995;91:2844-50

7. Cheng XW, Kuzuya M, Sasaki T, Kanda S, Tamaya-Mori N, Koike T, Maeda K, Nishitani E, Igutchi A. Green tea catechins inhibit neointimal hyperplasia in a rat carotid arterial injury model by TIMP-2 overexpression. Cardiovasc Res. 2004;62:594-602

8. Bendeck MP, Zempo M, Clowes AW, Galardy RE, Reidy MA. Smooth muscle cell migration and matrix metalloproteinase expression after arterial injury in rat. Circ Res. 1994;75:539-45

9. Pinney SP, Chen HJ, Liang D, Wang X, Schwartz A, Rabbani LE. Minocycline inhibits smooth muscle cell proliferation, migration and neointima formation after arterial injury. J Cardiovasc Pharmacol. 2003;42:469-76

10. Prescott MF, Sawyer WK, Von Linden-Reed J, Jeune M, Chou M, Caplan SL, Jeng AY. Effect of matrix metalloproteinase inhibition on progression of atherosclerosis and aneurysm in LDL receptor-deficient mice overexpressing MMP-3, MMP-12, and MMP-13 and on restenosis in rats after balloon injury. Ann N Y Acad Sci. 1999;878:179-90

11. Shepherd J, Cobbe SM, Ford I, Isles CG, Lorimer AR, MacFarlane PW, McKillop JH, Packard CJ. Prevention of coronary heart disease with pravastatin in men with hypercholesterolemia. West of Scotland Coronary Prevention Study Group. N Engl J Med. 1995;333:1301-7

12. Ridker PM, Danielson E, Fonseca FA, Genest J, Gotto AM Jr, Kastelein JJ, Koenig W, Libby P, Lorenzatti AJ, MacFadyen JG, Nordestgaard BG, Shepherd J, Willerson JT, Glynn RJ; JUPITER Study Group. Rosuvastatin to prevent vascular events in men and women with elevated C-reactive protein. N Engl J Med. 2008;359:2195-207

13. Waters D, Higginson L, Gladstone P, Kimball B, Le May M, Boccuzzi SJ, Lesperance J. Effects of monotherapy with an HMG-CoA reductase inhibitor on the progression of coronary atherosclerosis as assessed by serial quantitative arteriographie. The Canadian Coronary Atherosclerosis Intervention Trial. Circulation 1994;89: 959-68

14. Soma MR, Donetti E, Parolini C, Mazzini G, Ferrari C, Fumagalli R, Paoletti R. HMG-CoA reductase inhibitors. In vivo effects on carotid intimal thickening in normocholesterolemic rabbits. Arterioscler Thromb Vasc Res. 1993;13:571-8

15. Takemoto M, Liao JK. Pleiotropic effects of 3-hydroxy-3methylglutaryl coenzyme a reductase inhibitors. Arterioscler Thromb Vasc Biol 2001;21:1712-9

16. van der Harst P, Groenewegen HC, Roks AJ, Buikema H, Zijlstra F, van Gilst WH, de Smet BJ. Rosuvastatin attenuates angiotensin II-induced neointimal formation after stent implantation in the rat. Coron Artery Dis. 2008;19: 47-53

17. Kappert K, Leppänen O, Paulsson J, Furuhashi M, Carlsson MA, Heldin CH, Fätkenheuer G, Rosenkranz S, Ostman A. Highly active antiretroviral therapy attenuates reendothelialization and alters neointima formation in the rat carotid artery after balloon injury. J Acquir Immune Defic Syndr. 2006;43:383-92

18. McTaggart F, Buckett L, Davidson R, Holdgate G, McCormick A, Schneck D, Smith G, Warwick M. Preclinical and clinical pharmacology of rosuvastatin, a new 3-hydroxy-3-methylglutaryl coenzyme A reductase inhibitor. Am J Cardiol. 2001; 87: 28-32

19. Turner NA, O’Regan DJ, Ball SG, Porter KE. Simvastatin inhibits MMP-9 secretion from human saphenous vein smooth muscle cells by inhibiting the RhoA/ROCK pathway and reducing MMP-9 mRNA levels. FASEB J 2005;19:804-6

20. Evans J, Powell JT, Schwalbe E, Loftus IM, Thompson MM. Simvastatin attenuates the activity of matrix metalloproteinase-9 in aneurysmal aortic tissue. Eur J Vasc Endovasc Surg. 2007;100:23-7

21. Werner N, Priller J, Lauf U, Endres M, Böhm M, Dirnagl U, Nickenig G. Bone marrow-derived progenitor cells modulate vascular reendothelialization and neointimal formation: effect of 3-hydroxy-3-methylglutaryl coenzyme a reductase inhibition. Arterioscler Thromb Vasc Biol. 2002;22:1567-72

22. Lyons JG, Birkedal-Hansen B, Moore WGI, O`Grady RLO, Birkedal-Hansen H. Characteristics of a $95-\mathrm{kD}$ matrix-metalloproteinase produced by mammary carcinoma cells. Biochemistry 1991;30:1449-1456

23. Park SJ, Kim YH, Lee BK, Lee SW, Lee CW, Hong MK, Kim JJ, Mintz GS, Park SW. (2005) Sirolimus-eluting stent implantation for unprotected left main coronary artery stenosis: comparison with bare metal stent implantation. J Am Coll Cardiol 45:351-356

24. Maisel WH. Unanswered questions--drug-eluting stents and the risk of late thrombosis. N Engl J Med. 2007;356: 981-4

25. Topol EJ, Serruys PW. Frontiers in interventional cardiology. Circulation 1998;98:1802-20

26. Luan Z, Chase AJ, Newby AC. Statins inhibit secretion of metalloproteinases-1, $-2,-3$ and -9 from vascular smooth muscle cells in macrophages. Arterioscler Thromb Vasc Biol. 2003;23:769-75

27. Clowes AW, Reidy MA, Clowes MM. Kinetics of Cellular Proliferation after Arterial Injury I. Smooth Muscle Growth in the Absence of Endothelium. Lab Invest 1983;49:327-33

28. Indolfi C, Torella D, Coppola C, Stabile E, Esposito G, Curcio A, Pisani A, Cavuto L, Arcucci O, Cireddu M, Troncone G, Chiariello M. Rat carotid artery dilation by PTCA balloon catheter induces neointima formation in presence of IEL rupture. Am J Physiol Heart Circ Physiol. 2002;283:760-7

29. Kiyan J, Kusch A, Tkachuk S, Krämer J, Haller H, Dietz R, Smith G, Dumler I. Rosuvastatin regulates vascular smooth muscle cell phenotypic modulation in vascular remodeling: role for the urokinase receptor. Atherosclerosis. 2007;195:254-61

30. Bea F, Blessing E, Shelley MI, Shultz JM, Rosenfeld ME. Simvastatin inhibits expression of tissue factor in advanced atherosclerotic lesions of apolipoprotein $\mathrm{E}$ deficient mice independently of lipid lowering: potential role of simvastatin-mediated inhibition of Egr-1 expression and activation. Atherosclerosis. 2003;167:187-94

31. Dichtl W, Dulak J, Frick M, Alber HF, Schwarzacher SP, Ares MP, Nilsson J, Pachinger O, Weidinger F. HMG-CoA reductase inhibitors regulate inflammatory transcription factors in human endothelial and vascular smooth muscle cells. Arterioscler Thromb Vasc Biol. 2000;23:58-63

32. Han CI, Campbell GR, Campbell JH. Circulating bone marrow cells can contribute to neointimal formation. J Vasc Res 2001;38:113-119

33. Bauters C, Isner JM. The biology of restenosis. Prog Cardiovasc Dis. 1997;40:107-116

34. Llevadot J, Murasawa S, Kureishi Y, Uchida S, Masuda H, Kawamoto A, Walsh K, Isner JM, Asahara T. HMG-CoA reductase inhibitor mobilizes bone marrow-derived endothelial progenitor cells. J Clin Invest. 2001;108:399-405 
35. Clowes AW, Reidy MA, Clowes MM. Mechanisms of stenosis after arterial injury. Lab Invest. 1983;49:208-15.

36. Haudenschild CC, Schwartz SM. Endothelial regeneration. II. Restitution of endothelial continuity. Lab Invest. 1979;41:407-18

37. Schäfer K, Kaiser K, Konstandinides S. Rosuvastatin exerts favourable effects on thrombosis and neointimal growth in a mouse model of endothelial injury. Thromb Haemost. 2005;93:145-52

38. Glynn RJ, Danielson E, Fonseca FA, Genest J, Gotto AM Jr, Kastelein JJ, Koenig W, Libby P, Lorenzatti AJ, MacFadyen JG, Nordestgaard BG, Shepherd J, Willerson JT, Ridker PM. A randomized trial of rosuvastatin in the prevention of venous thromboembolism. N Engl J Med. 2009;360:1851-61

39. Ramcharan AS, Van Stralen KJ, Snoep JD, MantelTeeuwisse AK, Rosendaal FR, Doggen CJ. HMG-CoA reductase inhibitors, other lipid-lowering medication, antiplatelet therapy, and the risk of venous thrombosis. J Thromb Haemost. 2009;7:514-20

40. Tutar E, Ozcan M, Kilickap M, Gülec S, Aras O, Pamir G, Oral D, Dandelet L, Key NS. Elevated whole-blood tissue factor procoagulant activity as a marker of restenosis after percutaneous transluminal coronary angioplasty and stent implantation. Circulation. 2003;108:1581-4

41. Walter DH, Rittig K, Bahlmann FH, Kirchmair R, Silver M, Murayama T, Nishimura H, Losordo DW, Asahara T, Isner JM. Statin therapy accelerates reendothelialization: a novel effect involving mobilization and incorporation of bone marrow-derived endothelial progenitor cells. Circulation 2002;105:3017-24

42. Lee CH, de Feyter P, Serruys PW, Saia F, Lemos PA, Goedhart D, Soares PR, Umans VA, Ciccone M, Cortellaro M. Beneficial effects of fluvastatin following percutaneous coronary intervention in patients with unstable and stable angina: results from the Lescol intervention prevention study (LIPS). Heart 2004;90:1156-61
43. Ai M, Otokozawa S, Asztalos BF, Nakajima K, Stein E, Jones PH, Schaefer EJ. Effect of maximal doses of atorvastatin versus Rosuvastatin on small dense low-density lipoprotein cholesterol levels. Am J Cardiol 2008;101:315318

44. Dechend R, Fiebeler A, Park JK, Muller DN, Theuer J, Mervaala E, Bieringer M, Gulba D, Dietz R, Luft FC, Haller H. Amelioration of angiotensin II-induced cardiac injury by a 3-hydroxy-3-methylglutaryl coenzyme a reductase inhibitor. Circulation 2001; 104:576-581

45. Endo A, Tsujita Y, Kuroda M, Tanzawa K. Effects of ML-236B on cholesterol metabolism in mice and rats: lack of hypocholesterolemic activity in normal animals. Biochem Biophys Acta. 1979;575:266-276

46. Wang YX, Martin-McNulty B, Huw LY, da Cunha V, Post J, Hinchman J, Vergona R, Sullivan ME, Dole W, Kauser K. Anti-atherosclerotic effect of simvastatin depends on the presence of apolipoprotein E. Atherosclerosis. 2002;162: 23-31

47. Kita T, Brown MS, Goldstein JL. Feedback regulation of 3-hydroxy-3-methylglutaryl coenzyme A reductase in livers of mice treated with mevinolin, a competitive inhibitor of the reductase. J Clin Invest. 1980;66:1094-100

Received: March 5, 2010 / Accepted: May 11, 2010

Address for correspondence:

Michael R. Preusch, MD

Medizinische Klinik III

Universität Heidelberg

Im Neuenheimer Feld 410

69120 Heidelberg

Germany

Tel: $\quad+496221568611$

Fax: +496221565515

Email: michael.preusch@med.uni-heidelberg.de 